\title{
MOBILE-LEARNING FEEDBACK AND STUDENTS' SELF- EFFICACY IN NEW NORMAL POST COVID-19
}

\author{
Nurul Hidayah \\ STAIN Teungku Dirundeng Meulaboh - Nangroe Aceh Darussalam - Indonesia \\ ${ }^{1}$ nurulhidayah@staindirundeng.ac.id \\ Received: April, 2020; Accepted: July, 2020
}

\begin{abstract}
Nowadays, we live in a digital age and New Normal of COVID-19. There is a massive migration of face-to-face teaching learning method to online or mobil- teaching and learning. It is required to do a physical distancing among school members to stop the spreading of the COVID-19. Mobile-learning is a must to keep education process continue while we remain to stay at home. The successful of mobile teaching and learning process depends on several aspects, one of them is students' self-efficacy. Students' self-efficacy determines how hard students try to accomplish the task given and to the extent students commit taking part in the mobile learning process during this pandemic COVID-19. It also determines to what extent students want to challenge themselves. To sum up, self-efficacy plays a crucial role in students' achievement using mobile-learning method during this pandemic era. There is a significant relationship between feedback and self-efficacy. Therefore, educationalist is suggested to provide mobile-learning feedback to enhance students' self-efficacy to keep the students commit to taking part in the teaching-learning process. An elaborated feedback affected students' self-efficacy more although it is only a video feedback.
\end{abstract}

Keywords: Mobile-learning feedback, Self-Eficacy, New Normal Post COVID

\begin{abstract}
Abstrak
Saat ini, kita hidup di era digital dan New Normal of COVID-19. Ada migrasi besar-besaran metode pembelajaran tatap muka ke metode pembelajaran online. Pandemik ini sangat mengharuskan penerapan jarak fisik di kalangan anggota sekolah untuk menghentikan penyebaran COVID-19. Mobile-learning adalah suatu keharusan guna memastikan proses pendidikan terus berlanjut ketika kita dianjurkan untuk tetap di rumah. Keberhasilan proses pembelajaran dengan metode Mobile-Learning sangat tergantung pada beberapa aspek, salah satunya adalah Self-efficacy siswa. Self-efficacy siswa menentukan seberapa keras siswa berusaha menyelesaikan tugas dan sejauh mana siswa berkomitmen untuk mengambil bagian dalam proses pembelajaran Mobile-Learning selama pandemi COVID-19 ini. Ini juga menentukan sejauh mana siswa ingin menantang diri mereka sendiri. Singkatnya, self-efficacy memainkan peran penting dalam pencapaian siswa dalam pembelajaran Mobile-Learning selama era pandemi ini. Ada hubungan yang signifikan antara Feedback selama melaksanakan mobile-learning dan self-efficacy siswa. Oleh karena itu, pendidik disarankan untuk memberikan feedback selama pembelajaran mobile-learning untuk meningkatkan Self-efficacy siswa guna memastikan siswa berkomitmen untuk mengambil bagian dalam proses belajar-mengajar.
\end{abstract}

Kata Kunci: Mobile-learning feedback, Self-Eficacy, New Normal Post COVID

How to Cite: Hidayah, N. (2020). Mobile-Learning Feedback And Students' Self- Efficacy In New Normal Post Covid-19. Journal Of Educational Experts (JEE) 3 (2), 39-45.

\section{INTRODUCTION}

The pandemic of COVID-19 was firstly found in Wuhan, China in December 2019 (Shereen et al,2020 as cited in Cahapay,M.B, 2020). Furthermore, World Health Organization announced 
Covid-19

the global pandemic COVID-19 spreading in May 11, 2020 (Cahapay,M.B (2020), hence the psychical distancing is required to stop the spreading and Indonesia is no exception. Many schools require their students to remain at home, however, education or teaching learning process had to continue. This fact leads to the increase of the use of Mobile-learning tools in teaching and learning. Mobile learning which is commonly known as M-learning have been a popular trend among students. Rikala 2013 says that mobile learning is "learning in which learners are using mobile devices such as laptop, mobile phone, digital players, etc. to enhance learning by gaining knowledge, skills and experiences". Since Mobile means portable and movable, there are a lot of mobile learning devices.

There are many factors of successful learning process besides the learning applications. One of the factors is self-efficacy of student. Many experts defined what self-efficacy definition is, Bandura (1977) has written several articles on self-efficacy defines it as "People's judgments of their capabilities to organize and execute courses of action required to attain designated types of performances". Moreover, Ormrod (2011) said that self-efficacy plays an important role in how hard one's try to accomplish the task and to challenge it.

Boggiano \& Pittman et all., (2014 as cited in Ormrod 2011) says self-efficacy as " students' confidence about their ability to handle day-to-day tasks...". This may lead to students' achievement; therefore, the researcher pays attention on mobile-learning process students' selfefficacy. Moreover, Bandura (1997) argued that the development of belief in one's personal efficacy will change in response to experience, cognition, vicarious experience and social persuasion (as cited in Silmon 2011). Additionally, Rahil at all,, (2006) said that self-efficacy was enhanced when students perceived they performed well.

Therefore, the writers would like to investigate the relationship between M-learning feedback and students' self efficacy in learning. Although there are alot of researches on selfefficacy (e.g., Kamil \& Dairabi, 2012 ; Dimajani \& Fatemeh 2014 ) has conducted, unfortunately, such studies did not investigate the relationship between feedback and students' academic self-efficacy especially Mobil-learning-feedback.

According to Schunk 2008, performance feedback is feedback on the accuracy work which is included corrective information as well. The term of Mobile-learning-performance feedback, this study tries to seek the feedback influences that students got after doing a task on mobile phone or online evaluation.The M-leaning feedbacks received may influence students' self efficacy and their willingness to do an independent study during online teaching and learning process. In addition, this paper would like to investigate the correlation of feedback that students' mostly get on mobile-learning and its' effect on their self-efficacy.

\section{COMPRISING THE IMPORTANT ISSUES}

\section{Student Self Efficacy and Sources of It}

Self-efficacy refers to one' s belief about his/her capability to learn or to perform certain task (Bandura, 1986, 1997). Likewise, Mahyuddin (2006) argued that self-efficacy is one of measurements control over individual's thoughts, feelings and actions. In short, self-efficacy is the belief that students' hold about their capability mastering the subject that may influences their efforts and commitment in learning. Furthermore, there are many factors affects one's self efficacy. Bandura (1997) argued that self-efficacy belief are constructed from four main sources; Enactive Mastery Experiences, Vicarious experiences, verbal persuasion, and physiological and affective states.

Enactive Mastery Experiences refers to what people learn from their experience of success or failure (Kamil, 2012). This personal experience influences one's self efficacy most, therefore, Bandura (1994. P. 2) states "success helps build a strong sense of efficacy, while failure undermine it, particularly if failures occur before a sense of efficacy is firmly establish". 
Experiences in facing difficult tasks, problems and situations lead to a strong sense of self efficacy (Bandura, 1977). In term of learning, enactive mastery experiences related to students' perceived feedbacks.

Secondly, vicarious experiences mean people judgement about their capabilities by comparison with others. Individual may appraise their capability by observing others successes or failures experiences who are at the same level of knowledge or skills in executing given task (kamil, 2012. In other world, Vicarious experiences is mediated through modeled attainment.

Third, verbal persuasion which means "verbally persuaded that one's have the requisite knowledge or skill required to do a task given"'(Kamil, 2012. P. 30). This may lead to greater effort and maintain it if they pursue faces a difficult task, problems or situation. Finally, physiological and affective states which is related to tasks that need physical accomplishments (Bandura, 1997). To sum up, the lecturers should pay more attention on the four factors in increasing students' self-efficacy hence they commit in the online teaching-learning process during New Normal of COVID-19.

Additionally, the presentation of the review of previous researches is provided in a tabular form. The authors, years of publication, the focus of studies, settings, Sampling procedure, instruments and finding, validity and reliability are presented in the table below;

Table 1. Methodological Review of Research Evidence on Self-Efficacy

\begin{tabular}{|c|c|c|c|c|c|c|}
\hline $\begin{array}{l}\text { Author/ } \\
\text { Year } \\
\text { published }\end{array}$ & $\begin{array}{c}\text { Focus of the } \\
\text { study }\end{array}$ & $\begin{array}{l}\text { Research } \\
\text { Design }\end{array}$ & $\begin{array}{c}\text { Subject } \\
(\mathbf{n}) / \\
\text { setting }\end{array}$ & $\begin{array}{l}\text { Sampling } \\
\text { Procedure }\end{array}$ & $\begin{array}{l}\text { Instrument, } \\
\text { Validity \& } \\
\text { reliability }\end{array}$ & Result of the study \\
\hline $\begin{array}{l}\text { Becker } \\
\text { and } \\
\text { Gable } \\
(\mathbf{2 0 0 9 )}\end{array}$ & $\begin{array}{l}\text { Self-Efficacy } \\
\text { and GPA, } \\
\text { Attendance, } \\
\text { and College } \\
\text { Student }\end{array}$ & $\begin{array}{l}\text { Survey } \\
\text { questionnaire }\end{array}$ & $\begin{array}{l}\text { College } \\
\text { student= } \\
194\end{array}$ & Not reported & $\begin{array}{l}\text { Validity and } \\
\text { reliability } \\
\text { established }\end{array}$ & $\begin{array}{l}\text { Age and gender are } \\
\text { not related to success } \\
\text { at the study, however } \\
\text { there is a significant } \\
\text { relationship between } \\
\text { GPA, Attendance, } \\
\text { and retention. Self- } \\
\text { efficacy was equally } \\
\text { related to GPA. }\end{array}$ \\
\hline $\begin{array}{l}\text { Jain at al } \\
\text { (2006) }\end{array}$ & $\begin{array}{l}\text { Self-Efficacy } \\
\text { as a Function } \\
\text { of } \\
\text { Attributional } \\
\text { Feedback }\end{array}$ & $\begin{array}{l}\text { Survey } \\
\text { Questionnaire } \\
\text { And } \\
\text { experimental }\end{array}$ & $\begin{array}{l}\text { eighth } \\
\text { grade } \\
\text { students } \\
=192\end{array}$ & $\begin{array}{l}\text { random } \\
\text { selection } \\
\text { and follow- } \\
\text { up } \\
\text { recommend } \\
\text { ation by } \\
\text { mathematics } \\
\text { teacher }\end{array}$ & $\begin{array}{l}\text { Validity and } \\
\text { reliability } \\
\text { established }\end{array}$ & $\begin{array}{l}\text { improvement in self } \\
\text { efficacy judgments } \\
\text { was significantly } \\
\text { more for attributional } \\
\text { feedback conditions } \\
\text { as compared to no } \\
\text { attributional feedback } \\
\text { conditions }\end{array}$ \\
\hline $\begin{array}{l}\text { Parilah } \\
\text { M at al } \\
(\mathbf{2 0 1 1})\end{array}$ & $\begin{array}{l}\text { the } \\
\text { relationship } \\
\text { between the } \\
\text { learners' self- } \\
\text { efficacy and } \\
\text { their writing } \\
\text { performance } \\
\text { and } \\
\text { competence. }\end{array}$ & $\begin{array}{l}\text { writing } \\
\text { assessments } \\
\text { and } \\
\text { Questionnaire }\end{array}$ & $\begin{array}{l}\text { secondar } \\
\text { y school } \\
\text { students } \\
=120\end{array}$ & $\begin{array}{l}\text { Quota } \\
\text { sampling }\end{array}$ & $\begin{array}{l}\text { Adapted } \\
\text { from Pajares } \\
\text { (1996) }\end{array}$ & $\begin{array}{l}\text { There is a positive } \\
\text { correlation between } \\
\text { self-efficacy and } \\
\text { writing }\end{array}$ \\
\hline
\end{tabular}

\begin{tabular}{lllllll}
\hline $\begin{array}{l}\text { Rahil at } \\
\text { al (2006) }\end{array}$ & $\begin{array}{l}\text { The } \\
\text { relationship } \\
\text { between }\end{array}$ & $\begin{array}{l}\text { Survey } \\
\text { Questionnaire }\end{array}$ & $\begin{array}{l}\text { Eight } \\
\text { secondar } \\
\mathrm{y}\end{array}$ & $\begin{array}{l}\text { stratified } \\
\text { random }\end{array}$ & $\begin{array}{l}\text { Adopted } \\
\text { from }\end{array}$ & $\begin{array}{l}\text { Students with high } \\
\text { self efficacy often } \\
\text { display greater }\end{array}$ \\
\hline
\end{tabular}


Covid-19

\begin{tabular}{|c|c|c|c|c|c|c|}
\hline $\begin{array}{l}\text { Author/ } \\
\text { Year } \\
\text { published }\end{array}$ & $\begin{array}{c}\text { Focus of the } \\
\text { study }\end{array}$ & $\begin{array}{c}\text { Research } \\
\text { Design }\end{array}$ & $\begin{array}{c}\text { Subject } \\
(\mathbf{n}) / \\
\text { setting }\end{array}$ & $\begin{array}{l}\text { Sampling } \\
\text { Procedure }\end{array}$ & $\begin{array}{l}\text { Instrument, } \\
\text { Validity \& } \\
\text { reliability }\end{array}$ & Result of the study \\
\hline & $\begin{array}{l}\text { students' self- } \\
\text { efficacy and } \\
\text { their English } \\
\text { language } \\
\text { achievement }\end{array}$ & & $\begin{array}{l}\text { schools } \\
\text { students } \\
\mathrm{N}=1,146\end{array}$ & & $\begin{array}{l}\text { Bandura } \\
(1995), \\
\text { Kim and } \\
\text { Park (1997) }\end{array}$ & $\begin{array}{l}\text { performance } \\
\text { comparatively to } \\
\text { those with low } \\
\text { efficacy }\end{array}$ \\
\hline $\begin{array}{l}\text { Wang } \\
\text { and Wu } \\
(2008)\end{array}$ & $\begin{array}{l}\text { The role of } \\
\text { feedback and } \\
\text { self-efficacy } \\
\text { on web-based } \\
\text { learning }\end{array}$ & $\begin{array}{l}\text { Survey } \\
\text { questionnaire } \\
\text { and } \\
\text { Networked } \\
\text { portfolio } \\
\text { system }\end{array}$ & $\begin{array}{l}\text { College } \\
\text { students }\end{array}$ & $\begin{array}{l}\text { Not } \\
\text { mentioned }\end{array}$ & $\begin{array}{l}\text { Validity and } \\
\text { reliability } \\
\text { established }\end{array}$ & $\begin{array}{l}\text { Students who } \\
\text { provided elaborated } \\
\text { feedback had high } \\
\text { self-efficacy than } \\
\text { those who did not } \\
\text { and applied more } \\
\text { high-level learning } \\
\text { strategies. }\end{array}$ \\
\hline $\begin{array}{l}\text { Bobo and } \\
\text { Andrews }\end{array}$ & $\begin{array}{l}\text { Using video } \\
\text { feedback to } \\
\text { measure self- } \\
\text { efficacy }\end{array}$ & $\begin{array}{l}\text { Experimental } \\
\text { and survey } \\
\text { questionnaire }\end{array}$ & $\begin{array}{l}\text { athletic } \\
\text { training } \\
\text { educatio } \\
\text { nal } \\
\text { program } \\
\text { students } \\
(\mathrm{N}=3)\end{array}$ & Voluntary & $\begin{array}{l}\text { adapt the } \\
\text { instruments } \\
\text { from both } \\
\text { Dr. Douglas } \\
\text { Mann, PhD } \\
\text { (Mann \& } \\
\text { Eland, 2005) }\end{array}$ & $\begin{array}{l}\text { The use of video } \\
\text { feedback could } \\
\text { increase self-efficacy } \\
\text { when learning to } \\
\text { perform a PCS. }\end{array}$ \\
\hline $\begin{array}{l}\text { Yang and } \\
\text { Wu } \\
(\mathbf{2 0 1 3})\end{array}$ & $\begin{array}{l}\text { Effects of } \\
\text { Feedback } \\
\text { Types on the } \\
\text { Student's } \\
\text { Self-Efficacy } \\
\text { in Web based } \\
\text { learning }\end{array}$ & $\begin{array}{l}\text { Survey } \\
\text { questionnaire } \\
\text { and } \\
\text { experimental }\end{array}$ & $\begin{array}{l}\text { senior } \\
\text { high } \\
\text { school } \\
\text { students } \\
(\mathrm{N}=13)\end{array}$ & $\begin{array}{l}\text { Not } \\
\text { mentioned }\end{array}$ & $\begin{array}{l}\text { Validity and } \\
\text { reliability } \\
\text { established }\end{array}$ & $\begin{array}{l}\text { receiving KCR type } \\
\text { of feedback can } \\
\text { enhance student's } \\
\text { self-efficacy. }\end{array}$ \\
\hline $\begin{array}{l}\text { Zajacova } \\
\text { at al } \\
(\mathbf{2 0 0 5})\end{array}$ & $\begin{array}{l}\text { self-efficacy, } \\
\text { stress, and } \\
\text { academic } \\
\text { success in } \\
\text { college }\end{array}$ & $\begin{array}{l}\text { Survey } \\
\text { questionnaire }\end{array}$ & $\begin{array}{l}\text { College } \\
\text { Students } \\
\mathrm{N}=107\end{array}$ & $\begin{array}{l}\text { Not } \\
\text { mentioned }\end{array}$ & $\begin{array}{l}\text { Validity and } \\
\text { reliability } \\
\text { established }\end{array}$ & $\begin{array}{l}\text { academic self- } \\
\text { efficacy is a more } \\
\text { robust and consistent } \\
\text { predictor than stress } \\
\text { of academic success. }\end{array}$ \\
\hline $\begin{array}{l}\text { Wang at } \\
\text { al (2013) }\end{array}$ & $\begin{array}{l}\text { Examining } \\
\text { measurement } \\
\text { properties of } \\
\text { an English } \\
\text { self-efficacy } \\
\text { scale for } \\
\text { English } \\
\text { language } \\
\text { learners in } \\
\text { Korea }\end{array}$ & $\begin{array}{l}\text { Survey } \\
\text { Questionnaire }\end{array}$ & $\begin{array}{l}\text { Undergr } \\
\text { aduate } \\
\text { students } \\
\mathrm{N}=167\end{array}$ & $\begin{array}{l}\text { Convenienc } \\
\text { e sampling }\end{array}$ & $\begin{array}{l}\text { Validity and } \\
\text { reliability } \\
\text { established }\end{array}$ & $\begin{array}{l}\text { QESE largely satify } \\
\text { the Raschmodel for } \\
\text { unidimensionality } \\
\text { and listening } \\
\text { comprehension is the } \\
\text { most difficult task } \\
\text { while reading is the } \\
\text { easiest task }\end{array}$ \\
\hline $\begin{array}{l}\text { Chan and } \\
\text { Lam } \\
2010\end{array}$ & $\begin{array}{l}\text { the effects of } \\
\text { four types of } \\
\text { teachers' } \\
\text { evaluative } \\
\text { feedback on } \\
\text { Chinese } \\
\text { students' }\end{array}$ & Experimental & $\begin{array}{l}\text { Grade } 7 \\
\text { and } 8 \\
\text { students } \\
\mathrm{N}=156\end{array}$ & $\begin{array}{l}\text { Random } \\
\text { sampling }\end{array}$ & $\begin{array}{l}\text { Validity and } \\
\text { reliability } \\
\text { established }\end{array}$ & $\begin{array}{l}\text { Formative and self- } \\
\text { referenced feedback } \\
\text { encouraged students } \\
\text { to adopt a learning } \\
\text { goal that emphasized } \\
\text { incremental self- } \\
\text { improvement, while }\end{array}$ \\
\hline
\end{tabular}




\begin{tabular}{clccccc}
\hline $\begin{array}{c}\text { Author/ } \\
\text { Year } \\
\text { published }\end{array}$ & $\begin{array}{c}\text { Focus of the } \\
\text { study }\end{array}$ & $\begin{array}{c}\text { Research } \\
\text { Design }\end{array}$ & $\begin{array}{c}\text { Subject } \\
(\mathbf{n}) / \\
\text { setting }\end{array}$ & $\begin{array}{c}\text { Sampling } \\
\text { Procedure }\end{array}$ & $\begin{array}{c}\text { Instrument, } \\
\text { Validity \& } \\
\text { reliability }\end{array}$ & Result of the study \\
\hline $\begin{array}{l}\text { self-efficacy } \\
\text { in English } \\
\text { vocabulary }\end{array}$ & & & & $\begin{array}{l}\text { summative and norm- } \\
\text { referenced feedback } \\
\text { acquisition }\end{array}$ \\
& & & & & $\begin{array}{l}\text { pointed towards a } \\
\text { performance goal that } \\
\text { defined success as out } \\
\text { performing others. }\end{array}$ \\
\hline
\end{tabular}

\section{M-Learning-Feedback and Self-Efficacy in Islamic View}

"Read in the name of Allah" (al-Alaq 96;1)

This show us how Islam pay attention more on knowledge. The wise Umar bin Khatab, Khulafa "Al-Rasyid said " teach your children with contemporary knowledge for they are born in era which is different from yours". This emphasize that we should prepare our new generation the knowledge to challenge future in order to be better ummah. Islam encourage us to use the recent method and technology in line with the era and situation.

In term of self-efficacy, Noornajihan at al (2012) argued that self-efficacy as personal belief about one's ability to perform tasks will affect: 1) the actions and conduct of behavior, 2) the option to approach a situation and environment, 3) due to perform certain tasks. Moreover, Larson et al (1992, as cited in Noornajihan at al, 2012) argued that self-efficacy awareness create a link between one's knowledge and action so he/she perform tasks based on knowledge which is commonly known as " heart" in Islamic view. This is in line with the concept of purification of soul (al-nafs tazkiyah) introduced by al-Ghazali in which three elements (Mind, Liver, and Behaviors) take role. Noornajihan at al (2012) argued

"Mind represented by knowledge about Islam, the liver is represented by a person's faith or belief in God and behaviors, represented by the Muslim's individual actions in daily life".

\section{The Role of Feedbacks in Learning Process}

Many researches fund that feedback plays an important role in teaching and learning process. Feedback is the main recourses of information helping learners to correct the mistakes, improve academic achievement, and enhance motivation (Wang \& Wu, 2008). More over, according to Pintrick \& schunk (2002) feedback that emphasizes mastery, self-improvement, and achievement influences student's self-efficacy positively.

According to Wang and Wu (2008), There are three types of feedback used to assess feedback information: 1) knowledge of result ( KR) which means a simple verification toward learner's responses as true or false in task given, such as "you are righ". 2) knowledge of correct response (KCR) gives the learner the content of correct answer. 3) elaborated feedback (EF) that provides the information to help the learner to reason the correct answer. Since we live in the digital age, most of the activities need the advanced of technology and education is no exception.

\section{CONCLUSION}

There is a massive migration of face-to-face teaching learning method to online teaching learning due to pandemic COVID-19. It is required to do a physical distancing among school members to stop the spreading of the COVID-19 and mobile-learning is a must to keep education process continue while we remain to stay at home. The successful of mobile teaching and learning process depends on several aspects, one of them is students' self-efficacy. Students' self-efficacy determines how hard students try to accomplish the task and to the extent 
Covid-19

students commit take part in the mobile learning process during this pandemic COVID-19. It also determines to what extent students want to challenge themselves. To sum up, self-efficacy play a crucial role in students' achievement in mobile-learning during this pandemic era. Additionally, Educationalists should enhance students' self-efficacy by providing the positive feedback during mobile-learning. Elaborated feedback affected students' self-efficacy more although it is only a video feedback.

\section{REFERENCES}

Ashton, P. T., \& Webb, R. B. (1986). Making a difference: Teachers' sense of efficacy and student achievement.New York: Longman.

Bandura, A (1997). Self- efficacy: The exercise of control. New York: W.H.Freeman and Company.

Bandura, A. (1997). Self-efficacy: The exercise of control. New York: Freeman.

Bandura, A. (2001). Social cognitive theory: An agentic perspective. Annual Review of Psychology, 52, 1-26.

Bobo, L., \& Andrews, A. (2010). Using video feedback to measure self-efficacy. Journal of Instructional Pedagogies, 3, 1-11.

Cahapay, M. B. (2020). Rethinking Education in the New Normal Post-COVID-19 Era: A Curriculum Studies Perspective. Aquademia, 4(2), ep20018. https://doi.org/10.29333/aquademia/8315

Chan, J. C. Y., \& Lam, S. (2010). Effects of different evaluative feedback on students' selfefficacy in learning. Instructional Science, 38(1), 37-58. http://doi.org/10.1007/s11251008-9077-2

Gibbs, S \& Powell, B (2011). Teacher efficacy and pupil behaviour: the structure of teachers' individual and collective beliefs and their relationship with number of pupils excluded from school. British journal of educational psycholog (2011). 82, 565-584. UK.

Jain, S., Bruce, M. A., Stellern, J., \& Srivastava, N. (2006). Self-Efficacy as a Function of Attributional Feedback. Journal of School Counseling, 5(4). Retrieved from http://eric.ed.gov/?q=Bandura\&ft=on\&id=EJ901165

Journal, B., Vol, E., Centre, E., \& Uk, D. (2014). Academic Self-Efficacy: a Reliable Predictor of Educational Performances. British Journal of Education, 2(3), 57-64.

Kamil, Dairabi. Secondary school EFL teacher's self-efficay, understanding of, and practices in school-based curriculum development in the district of Kerinci, Indonesia; IIUM Desertation, 2012

Mahyuddin, R., Elias, H., Cheong, L. S., Muhamad, M. F., Noordin, N., \& Abdullah, M. C. (2006). the Relationship Between Students' Self Efficacy and Their English Language Achievement. Jurnal Pendidik Dan Pendidikan, Jil.21(1996), 61-71.

Noornajihan Jaafar, Ab. Halim Tamuri, Ghazali, N. M., Amat, R. A. M. @, Raus, N. M., \& Hassan, S. N. S. (2012). The Importance of Self-Efficacy: A Need for Islamic Teachers as Murabbi. Procedia - Social and Behavioral Sciences, 69(Iceepsy), 359-366. http://doi.org/10.1016/j.sbspro.2012.11.421

Ormrod, Jeanne Ellis (2011). Educational Psychology: developing learners. United States of America: Pearson.

Shah, P. M., Hamiah, W., Mahmud, W., \& Din, R. (2011). Self-Efficacy in the Writing of Malaysian ESL Learners, 15, 8-11.

Vittorio, G., Barbaranelli C., Steca p., at all (2006). Teachers' self-efficacy beliefs as determinants of job satisfaction and students' academic achievement:A study at the school level. Journal of School Psychology 44 (2006) 473-490. 
Wang, C., Kim, D.-H., Bong, M., \& Ahn, H. S. (2013). Examining measurement properties of an English Self-Efficacy scale for English language learners in Korea. International Journal of Educational Research, 59, 24-34. http://doi.org/10.1016/j.ijer.2013.02.004

Wang, S.-L., \& Wu, P.-Y. (2008). The role of feedback and self-efficacy on web-based learning: The social cognitive perspective. Computers \& Education, 51, 1589-1598. http://doi.org/10.1016/j.compedu.2008.03.004

Yang, K.-H. (2013). Effects of Feedback Types on the Student's Self-Efficacy. International Journal of E-Education, E-Business, E-Management and E-Learning, 3(3), 10-13. http://doi.org/10.7763/IJEEEE.2013.V3.223

Zajacova, A., Lynch, S. M., \& Espenshade, T. J. (2005). Self-Efficacy, Stress, and Academic Success in College. Research in Higher Education, 46(6), 677-706. http://doi.org/10.1007/s11162-004-4139-z. 